\title{
PEMBENIHAN CACING LAUT Dendronereis pinnaticirris: SUATU UPAYA AWAL PENYEDIAAN BENIH CACING LAUT UNTUK BUDIDAYA
}

\author{
Rasidi \\ Pusat Penelitian dan Pengembangan Perikanan Budidaya \\ Jl. Ragunan 20, Pasar Minggu, Jakarta Selatan 12540 \\ E-mail: rasidi_clp@yahoo.com
}

\begin{abstract}
ABSTRAK
Ketersediaan benih mutlak diperlukan untuk mencukupi kebutuhan budidaya baik jumlah maupun kualitasnya. Budidaya cacing laut (marine worm aquaculture) juga memerlukan ketersediaan benih yang akan dipelihara. Salah satu usaha untuk penyediaan benih dapat dilakukan dengan melakukan pemijahan secara eksternal. Teknologi pembenihan cacing laut Dendronereis pinnaticirris telah berhasil dilakukan skala laboratorium. Hal ini menjadi salah satu kemajuan yang dapat dijadikan referensi untuk pemijahan cacing laut jenis yang lain di Indonesia. Mengingat ketersediaan data dan informasi mengenai teknologi budidaya cacing laut di Indonesia masih sangat terbatas. Sementara di beberapa negara misal nya di Inggris dan Australia budidaya cacing laut telah berkembang dan produknya telah diekspor ke berbagai negara, sehingga cacing laut telah menjadi salah satu sumber devisa negara. Sementara di Indonesia cacing laut belum banyak dilakukan penelitian budidayanya. Peluang penelitian dan pengembangan budidaya cacing laut di Indonesia masih terbuka lebar dalam rangka penyediaan pakan alami untuk induk udang di pembenihan udang.
\end{abstract}

KATAKUNCl: cacing laut, teknologi pembenihan, pembenihan udang, dan pakan alami

\section{PENDAHULUAN}

Kegiatan budidaya perikanan pada umumnya sangat tergantung pada ketersediaan benih. Teknologi pembenihan ikan budidaya sudah sangat maju dan dikuasai oleh masyarakat umum, sehingga benih ikan mampu diproduksi skala massal oleh pembenihan di Balai Benih Ikan dan unit pembenihan rakyat yang ada di masyarakat. Kemajuan teknologi pembenihan ikan budidaya dapat berhasil dan berkembang di masyarakat merupakan hasil penelitian dan pengembangan yang dilakukan dalam jangka waktu yang panjang.

Secara umum jika dibandingkan antara teknologi pembenihan ikan dengan teknologi pembenihan cacing laut di Indonesia masih sangat terbatas. Hal ini disebabkan oleh banyak faktor antara lain cacing laut belum dianggap komoditas penting sehingga perhatiannya juga masih sangat kurang dibandingkan dengan komoditas perikanan yang lain.

Menurut Rahmad \& Yuwono (2000), cacing lur mempunyai kandungan protein sebesar $56,29 \%$ lemak $11,32 \%$ Jika dilihat dari potensinya kandungan nutrisi cacing laut mengandung kandungan nutrisi yang tinggi antara lain protein, lemak, dan hormon prostaglandin sehingga mampu memenuhi kebutuhan nutrisi induk udang dan ikan dalam proses pematangan gonadnya (Yuwono, 2005).

Dari aspek ekonomis cacing laut juga mempunyai nilai ekonomis yang tinggi. Berdasarkan hasil survai di beberapa sentra pembenihan udang di Serang, Cilacap, Situbondo, dan Barru diperoleh informasi sebagian besar pembenihan udang memanfaatkan cacing laut sebagai salah satu pakan alami untuk induk udang, harganya berkisar Rp 22.000,--Rp 50.000,- dengan rata-rata Rp 32.315,-/kg (Rasidi, 2012). Cacing laut telah dimanfaatkan sebagai salah satu pakan alami yang sangat dibutuhkan untuk kelangsungan produksi nauplii udang di pembenihan udang. Hal ini menjadi peluang untuk pemasaran hasil budidaya cacing laut.

Penyediaan pakan alami di pembenihan udang, selama ini pembenihan udang memperoleh cacing laut diperoleh dari pedagang pengumpul hasil tangkapan di alam. Hasil tangkapan cacing dari alam sangat tergantung pada kondisi cuaca dan musim, sehingga ketersediaan cacing laut seringkali menjadi kendala di pembenihan udang. Selain itu, dari aspek biosecurity cacing laut hasil tangkapan di alam sering dianggap sebagai pembawa penyakit dan bahan-bahan toksik lain yang dapat membahayakan induk udang. 
Salah satu alternatif untuk mengatasi hal tersebut dengan cara budidaya cacing laut. Budidaya cacing laut membutuhkan benih cacing laut yang akan dipelihara, ketersediaan benih dapat dilakukan dengan melakukan pemijahan secara artifisial. Makalah ini menyajikan informasi teknologi budidaya cacing laut khususnya pembenihan cacing laut Dendronereis pinnaticirris. Tulisan ini mencakup aspek biologi, siklus hidup, dan teknik pembenihan cacing laut. Manfaat dari tulisan ini diharapkan teknologi pembenihan cacing laut jenis ini dapat dijadikan referensi untuk penelitian budidaya cacing laut jenis yang lain terutama aspek pembenihannya.

\section{Aspek Biologi Cacing Laut Dendronereis pinnaticirris}

Salah satu jenis cacing laut yang telah berhasil dipijahkan skala laboratorium yaitu Dendronereis pinnaticirris. Klasifikasi menurut World Organisme Marine (2010), Dendronereis pinnaticirris Grube, 1878 termasuk dalam filum Annelida, kelas Polychaeta, famili Nereididae, dan genus Nereis. Cacing laut di beberapa daerah mempunyai nama lokal yang berbeda-beda misalnya di Jawa Tengah cacing laut dikenal dengan nama lokal cacing welur atau lur (Yuwono, 2003).

Secara morfologi stuktur badan luarnya dapat dideskripsikan sebagai berikut: ciri khas yang dimiliki cacing laut yaitu badannya tersusun atas segmensegmen, memiliki sepasang parapodia dan ber-chaetae pada setiap segmen badannya, memiliki 2 pasang mata di kepala dan cilia rastomial 4 pasang, mempunyai sepasang rahang chitin dan pharynk musculer yang dapat digerakkan membentuk sepasang proboris serta warna badannya merah kecoklatan (Gambar 1).

\section{Teknik Pembenihan Cacing Laut}

\section{Persiapan}

Cacing laut banyak ditemukan di dasar perairan kawasan tambak, mangrove, dan laut. Cacing D. pinnaticirrisyang telah berhasil dipijahkan berasal di Desa Randusanga, Brebes, Jawa Tengah. Kawasan ini sebagian besar berupa tambak tradisional yang digunakan untuk budidaya udang dan bandeng oleh masyarakat setempat.

Pengambilan induk cacing laut dilakukan secara manual dengan tangan. Hal ini dimaksudkan agar badan cacing tidak mengalami luka atau putus, sehingga cacing masih dalam keadaan utuh dan hidup. Kemudian cacing ditampung di kotak plastik yang diberi air tambak.

Tahap persiapan dapat dilihat pada Gambar 2. Cacing hasil tangkapan di alam kemudian dibersihkan dan dibawa ke laboratorium Fakultas Biologi Unsoed Purwokerto sebagai bahan percobaan. Di laboratorium cacing ditempatkan di ember yang diberi aerator untuk mensuplai oksigen sehingga cacing dalam keadaan hidup. Tahap selanjutnya cacing ditempatkan dalam kotak plastik. Selanjutnya dilakukan pengamatan tingkat kematangan sel gamet di mikroskop.

\section{Pengamatan Sel Gamet}

Pengamatan sel gamet dilakukan setiap hari di bawah mikroskop. Pengamatan sel gamet dimaksudkan untuk melihat perkembangan sel gamet yang siap dipijahkan. Hal ini dilakukan karena ketika cacing laut belum mengalami matang gonad untuk membedakannya masih sangat sulit, namun cacing yang sudah matang kelamin secara morfologi dapat dibedakan antara jantan dan betina. Menurut Yuwono et al. (2002), secara morfologis untuk memudahkan membedakan antara jantan dan betinanya dapat dilihat dari warna badannya. Badan cacing jantan yang sudah matang kelamin akan berwarna putih, sedangkan cacing betina ketika sudah matang kelamin akan berwarna hitam kehijauan.

Sebelum dilakukan fertilisasi, dilakukan pengamatan oosit dan spermatozoa diamati untuk mengetahui tingkat kematangannya. Oosit dan spermatozoa diambil dari rongga coelom hewan betina dan jantan menggunakan

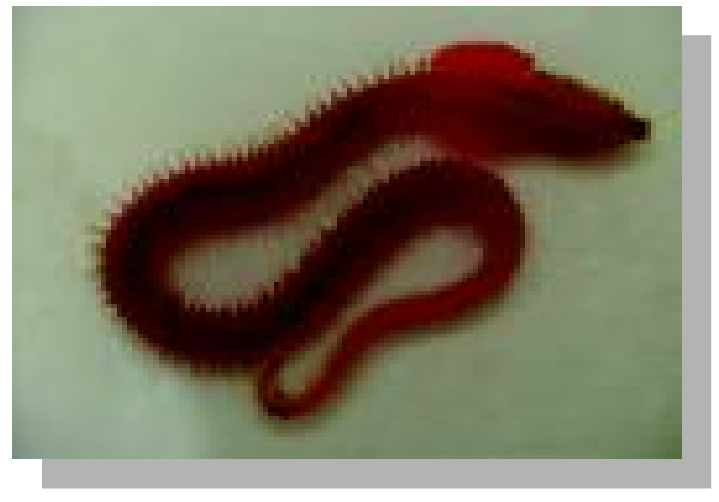

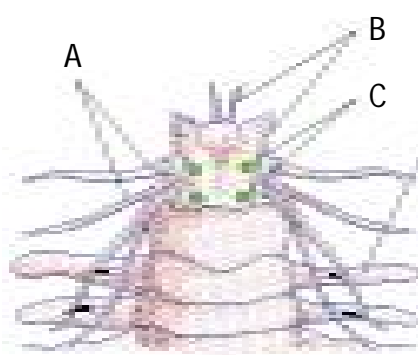
A. Tentacles
B. Sensory papillae
C. Eyes

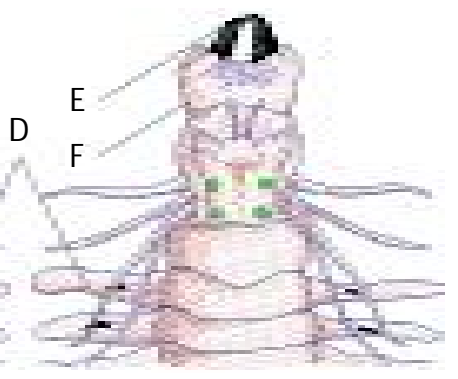

D. Parapodia

E. Jaws

F. Everted pharynx

Gambar 1. Morfologi cacing Dendronereis pinnaticirris 


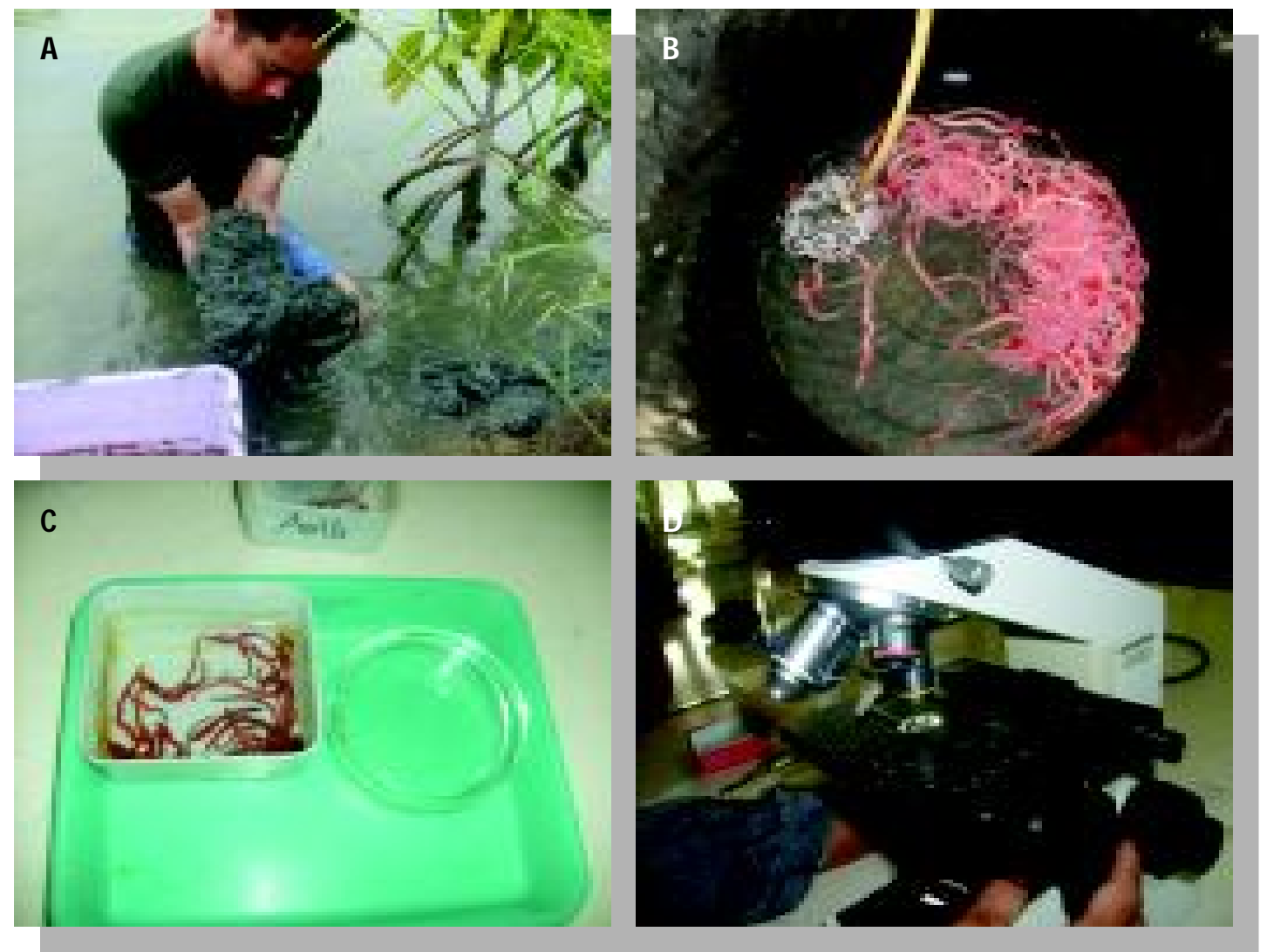

Gambar 2. Persiapan pembenihan cacing laut skala laboratorium, (A) pengambilan di tambak, (B) penampungan sementara di laboratorium, (C) penempatan dalam wadah, (D) cacing siap diamati perkembangan gamet di bawah mikroskop

pipa kaca berdiameter $1 \mathrm{~mm}$. Dalam upaya menghasilkan benih cacing laut dilakukan fertilisasi dalam wadah berisi air dengan salinitas 15-17 ppt. Oosit yang difertilisasi diperoleh dari induk yang matang secara alami. Spermatozoa juga diperoleh dari induk yang telah matang sempurna secara alami, tanpa dilakukan manipulasi.

\section{Siklus Hidup}

Sebagian besar cacing Polychaeta reproduksinya bersifat monotelic, yaitu hewan yang hanya mengalami satu kali reproduksi selama siklus hidupnya (Golding \& Yuwono, 1994; Yuwono, 2008) (Gambar 3). Cacing lur memiliki kelamin terpisah, perbedaan jantan dan betina pada saat sebelum matang gonad sangat sulit dibedakan secara morfologis. Pada saat matang gonad mengalami perubahan warna, cacing betina menjadi hitam kehijauan, dan cacing jantan badannya berubah berwarna putih.

\section{Fertilisasi}

Pada waktu memijah hewan jantan dan betina akan mengeluarkan sperma dan telur ke perairan dan fertilisasi terjadi secara eksternal dalam perairan (Yuwono, 2003).
Untuk fertilisasi artifisial dapat dilakukan dengan mencampurkan sel telur dan spermatozoa yang masak alami maupun dengan manipulasi hormonal (Yuwono et al., 2002).

Menurut Yuwono et al. (2002), fertilisasi dilakukan dengan mencampurkan oosit yang matang sempurna sebanyak 5 cc dengan suspensi spermatozoa yang motil sebanyak 1 cc dalam cawan plastik berisi medium sebanyak 200 cc. Setelah 5 menit dari saat pencampuran oosit dan spermatozoa, dilakukan pengamatan terhadap oosit untuk mengetahui terbentuknya selaput fertilisasi sebagai pertanda keberhasilan fertilisasi. Oosit yang telah membentuk selaput fertilisasi, selanjutnya akan mengalami pembelahan menjadi 2, 4, 8 sel dan seterusnya sehingga membentuk morula. Sampai dengan hari ke-4, larva cacing baru ditempatkan di substrat lumpur yang diambil dari tambak.

\section{KESIMPULAN}

Cacing laut D. pinnaticirris telah berhasil dipijahkan dengan menghasilkan benih cacing laut. Teknologi pembenihan cacing laut ini dapat dijadikan sebagai acuan 


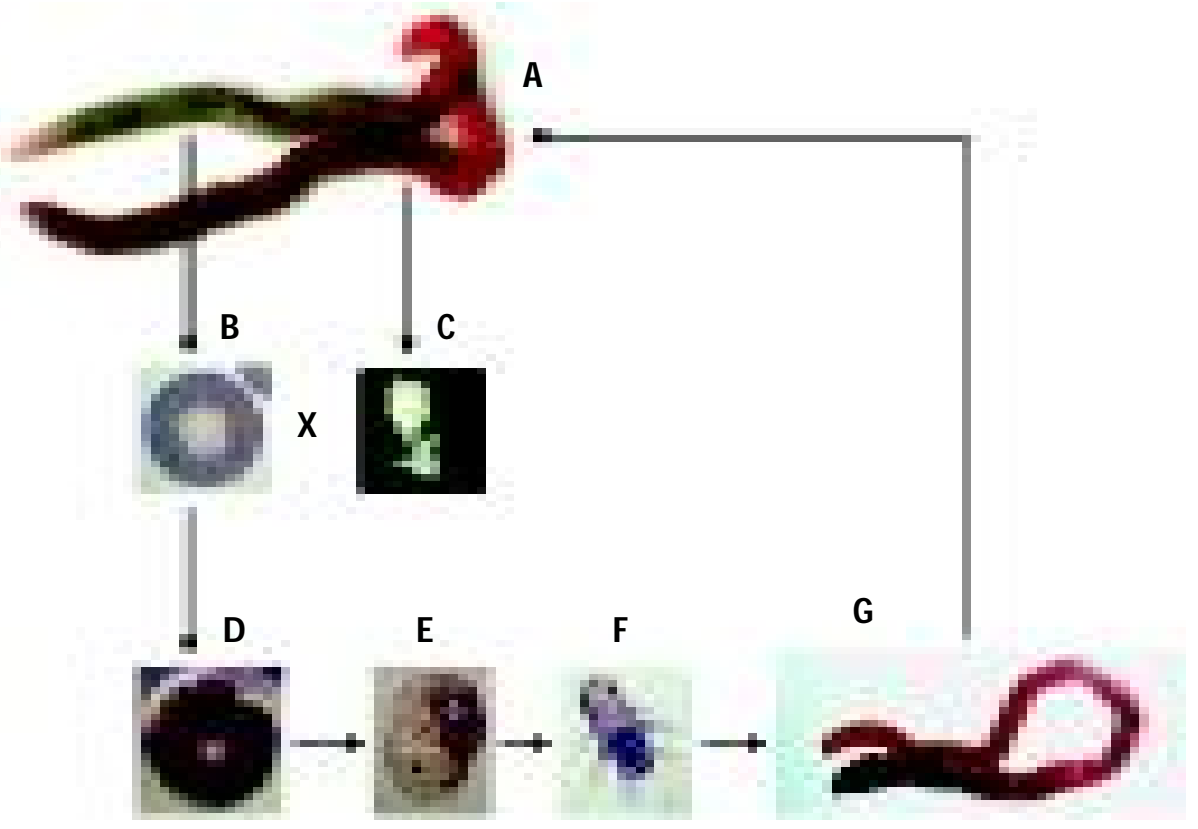

Gambar 3. Siklus hidup cacing welur D. pinnaticirris, (A) cacing dewasa menghasilkan oosit, (B) yang dibuahi oleh spermatozoa, (C) oosit yang telah dibuahi, (D) mengalami pembelahan dan berkembang menjadi trokofor, (E) planktonik, kemudian membentuk larva dengan 3 setiger, $(F)$ bentik dan selanjutnya tumbuh menjadi yuwana, (G) yang berkembang menjadi cacing dewasa (Sumber: Yuwono, 2008)

selanjutnya untuk pembenihan cacing laut jenis yang lain. Budidaya cacing laut sangat diharapkan oleh pembenihan udang yang selama ini memanfaatkannya sebagai pakan alami untuk induk udang. Dengan diperolehnya teknologi pembenihan cacing laut ini diharapkan budidaya cacing laut dapat berkembang lebih maju. Peluang sekaligus tantangan penelitian dan pengembangan terhadap cacing laut masih terbuka lebar.

\section{UCAPAN TERIMA KASIH}

Penulis mengucapkan banyak terima kasih kepada Drs. Untung Susilo, M.S. dan Eko Setiowibowo, M.Si. yang telah memberikan materi pelatihan pembenihan cacing laut di Fakultas Biologi Unsoed Purwokerto. Selain itu, penulis juga mengucapkan terima kasih kepada Sdr. Teguh, S.Pi. dan Sdr. Sophan S.Pi. atas bantuannya di lapangan.

\section{DAFTAR ACUAN}

Golding, D.W. \& Yuwono, E. 1994. Latent capacities for gametogenic cycling in the semelporous invertebrata Nereis. Proc. Natl. Acad. Sci., 91: 11,777-11,781.

Rahmad, B. \& Yuwono, E. 2000. Pertumbuhan dan laju makan serta efisiensi protein pada post larva udang windu yang diberi pakan mengandung tepung cacing Iur. Makalah Seminar Nasional Biologi XVI di ITB, Bandung, $9 \mathrm{hlm}$.
Rasidi. 2012. Pertumbuhan, sintasan, dan kandungan nutrisi cacing Polychaeta Nereis sp. yang diberi jenis pakan berbeda dan kajian pemanfaatan Polychaeta oleh masyarakat sebagai pakan induk di pembenihan udang. Tesis. Fakultas MIPA Program Pascasarjana Biologi. Universitas Indonesia. Depok.

Yuwono, E. 2003. Studi aspek fisiologi untuk aplikasi dalam budidaya cacing lur (Nereis sp.). Sains Akuatik, 6(3): 66-74.

Yuwono, E., Haryadi, B., Susilo, U., Sahri, A., \& Sugiharto. 2002. Fertilisasi serta pemeliharaan larva dan yuwana sebagai upaya pengembangan teknik budidaya cacing lur. Biosfera, 19(3): 20-26.

Yuwono, E. 2005. Kebutuhan nutrisi Crustacea dan potensi cacing lur (Nereis, Polychaeta) untuk pakan udang. Jurnal Pembangunan Pedesaan, V(1): 42-49.

Yuwono, E. 2008. Reproduksi dan fertilisasi welur (Dendronereis pinnaticirris). Makalah disampaikan Pelatihan Pembenihan Welur (Dendronereis pinnaticirris), 14-15 November 2008 di Fakultas Biologi Universitas Jenderal Soedirman, Purw okerto, Jawa Tengah, $6 \mathrm{hlm}$.

WoRMS (2010). Dendronereis pinnaticirris Grube, 1878. In: Fauchald, K. (Ed) (2010). World Polychaeta database. Accessed through: World Register of Marine Species at http://www.marinespecies.org/aphia.php?p= taxdetails\&id= 326901. 5 Februari 2011.pukul 08.49 WIB. 